\title{
PENERAPAN PEMBELAJARAN INVESTIGASI KELOMPOK TERHADAP HASIL BELAJAR MATEMATIS SISWA SEKOLAH MENENGAH PERTAMA
}

\author{
Rusdian Rifa'i', Nenden Suciyati Sartika' \\ 1Program Studi Pendidikan Matematika Universitas Mathla'ul Anwar \\ Jalan Raya Labuan KM 23, Cikaliung, Saketi, Sindanghayu, Saketi, Kabupaten \\ Pandeglang, Banten \\ Email : rusdianrifai@gmail.com
}

\begin{abstract}
ABSTRAK
Penelitian ini bertujuan untuk melihat pengaruh penerapan pembelajaran investigasi kelompok terhadap hasil belajar matematis siswa Sekolah Menengah Pertama. Penelitian ini menggunakan metode eksperimen yang berdesain kelompok kontrol pretes-postes. Populasi penelitian ini adalah seluruh siswa Sekolah Menengah Pertama Negeri 40 Bandung, sedangkan yang dijadikan sampel adalah siswa kelas VIII yang dipilih secara acak berdasarkan kelas. Instrumen yang digunakan dalam penelitian ini adalah tes tipe uraian yang disusun berdasarkan indikator-indikator hasil belajar matematika. Statistik yang digunakan dalam manganalisis data hasil penelitian adalah statistik parametrik dengan uji-t. Berdasarkan hasil analisis data, diperoleh kesimpulan bahwa hasil belajar matematis siswa yang memperoleh pembelajaran investigasi kelompok lebih baik daripada hasil belajar matematis siswa yang memperoleh pembelajaran konvensional.
\end{abstract}

Kata kunci: Pembelajaran investigasi kelompok, hasil belajar matematis.

\begin{abstract}
This study aims to see the effect of applying group investigation learning to mathematical learning outcomes of Junior High School students. This study used an experimental method that designed the pretest-postes control group. The population of this study is all students of State Junior High School 40 Bandung, while the sample is a class VIII students are selected at random based on the class. The instrument used in this study is a type of description test that is based on indicators of mathematics learning outcomes. The statistic used in analyzing the research data is parametric statistic with $t$-test. Based on the result of data analysis, it can be concluded that the mathematical learning outcomes of students who acquired group investigation learning is better than the mathematical learning outcomes of students who obtain conventional learning.
\end{abstract}

Keywords: Learning group investigation, mathematical learning outcomes. 


\section{PENDAHULUAN}

Perkembangan ilmu pengetahuan dan teknologi telah membawa perubahan dihampir semua aspek kehidupan manusia. Oleh karena itu, diperlukan suatu upaya penguasaan dan peningkatan ilmu pengetahuan dan teknologi, agar mampu berperan dalam persaingan global. Peningkatan ilmu pengetahuan dan teknologi merupakan hal yang perlu dikembangkan setiap individu dalam menghadapi tantangan hidup yang muncul dari adanya perkembangan zaman saat ini (Nia, Effendi, \& Farlina, 2017). Sumber daya manusia perlu dikembangkan dan ditingkatkan kualitasnya. Dalam rangka meningkatkan kualitas sumber daya manusia yang mampu bersaing secara global, Depdikbud (Yunita dan Poedjadi, 2001) menyatakan bahwa menetapkan empat tema pokok kebijakan pendidikan. Salah satu kebijakan tersebut adalah meningkatkan kualitas semua jenis dan jenjang pendidikan yang diarahkan pada upaya peningkatan kualitas proses dan hasil pendidikan.

Semiawan (Yunita dan Poedjadi, 2001) menyatakan bahwa suatu sistem pendidikan disebut bermutu dari segi proses apabila proses belajar mengajar berlangsung secara efektif dan siswa mengalami pembelajaran yang bermakna dan ditunjang oleh sumber daya yang memadai. Hal ini sejalan dengan pendapat Apriyanto (2002: 1) yang menyatakan bahwa pengajaran yang baik adalah pengajaran yang tidak semata-mata berorientasi kepada hasil, tetapi juga berorientasi pada proses, dengan harapan semakin tinggi kualitas proses semakin tinggi pula hasil belajar yang diperoleh. Dalam hal ini proses pembelajaran di sekolah merupakan suatu proses yang melibatkan siswa dan guru untuk mewujudkan hasil belajar yang optimal.

Usaha perbaikan pembelajaran yang dilakukan di sekolah-sekolah belum memberikan hasil belajar matematika siswa yang memuaskan. Studi yang dilakukan Wahyudin (1999) memperlihatkan bahwa hasil belajar matematika sekolah menengah belum memuaskan dan siswa masih mengalami kesulitan dalam belajar matematika. Selain hasil belajar rendah, ternyata motivasi siswa untuk belajar matematika kurang antusias, dan aktivitas siswa kurang berperan dengan baik walaupun strategi pembelajaran yang digunakan adalah cooperative learning yang melibatkan siswa mengkonstruksi pengetahuannya sendiri, tetapi pada kenyataannya siswa masih bergantung pada guru walaupun kadang-kadang ada siswa yang ingin bertanya atau mengeluarkan pendapatnya, tetapi yang melakukan kegiatan ini hanya satu atau dua orang saja. Padahal di lain pihak pendidikan matematika sangat penting untuk berpikir dan berargumentasi.

Masalah rendahnya hasil belajar siswa ini tentu saja harus disikapi dengan serius. Banyak faktor yang mempengaruhinya. Ruseffendi (1991: 9) menyatakan bahwa keberhasilan belajar siswa dipengaruhi oleh faktor dalam dan faktor luar. Faktor dalam meliputi kecerdasan anak, kesiapan anak, bakat anak, kemauan belajar, dan minat anak. Faktor luar terdiri dari model penyajian materi, pribadi, sikap guru, suasana belajar, kompetensi guru, dan kondisi luar. Salah satu tugas seorang guru dalam proses pembelajaran adalah menciptakan suatu lingkungan yang dapat mendorong siswa untuk belajar secara aktif. Ruseffendi (1991: 283) menyatakan bahwa belajar secara aktif dapat menyebabkan ingatan yang dipelajari lebih tahan lama dan pengetahuan akan menjadi lebih luas daripada belajar pasif. Tugas guru adalah membantu dan mengarahkan siswa serta menjadi motor penggerak yang dapat membuat siswa lebih termotivasi dalam belajar.

Untuk itu diperlukan suatu perubahan dan perbaikan dalam pembelajaran guna menciptakan suasana belajar yang kondusif, konstruktif, demokratis, dan kolaboratif. Suasana belajar yang demikian sangat memungkinkan tumbuhnya cara-cara belajar kerjasama dan melakukan kegiatan belajar mengajar secara gotong royong. Istilah yang 
Penerapan Pembelajaran Investigasi Kelompok Terhadap Hasil Belajar Matematis Siswa Sekolah Menengah Pertama

lebih popularnya disebut pembelajaran kooperatif. Dalam pembelajaran kooperatif terdapat berbagai tipe pembelajaran. Salah satu diantaranya adalah tipe investigasi kelompok. The Cocroft Report (Setiawan, 2006: 2) merekomendasikan bahwa pembelajaran matematika pada semua level pendidikan, seharusnya meliputi kesempatan berlangsunnya kegiatan pendahuluan dari guru, diskusi antara guru dengan siswa, diskusi antar siswa, adanya kerja praktek, dan kerja investigasi. Setiawan (2006: 9) menyatakan bahwa investigasi mendorong siswa untuk belajar lebih aktif dan lebih bermakna, artinya siswa dituntut untuk selalu berpikir tentang suatu persoalan dan mencari sendiri cara penyelesaiannya. Dengan demikian mereka akan lebih terlatih untuk selalu menggunakan keterampilan pengetahuannya.

Pembelajaran investigasi kelompok merupakan salah satu tipe dari model pembelajaran kooperatif. Dalam model ini siswa belajar dalam kelompok-kelompok heterogen yang terdiri atas dua sampai enam anggota untuk menemukan atau menyelesaikan masalah. Suwangsih (2004: 25) menyatakan bahwa investigasi kelompok merupakan salah satu pembelajaran yang membangkitkan minat siswa belajar lebih aktif, membiasakan siswa berpikir ilmiah, karena investigasi kelompok merupakan pengajaran pemecahan masalah pada masalah-masalah yang divergen. Mafruroh (2004: 3) menyatakan bahwa investigasi kelompok juga dapat digunakan untuk membimbing siswa agar dapat berpikir sistematis, kritis, analitis, berpartisipasi aktif dalam belajar, dan berbudaya kreatif melalui kegiatan untuk merasakan masalah dengan rangsangan-rangsangan pertanyaan dan dorongan untuk mencari informasi yang berkaitan dengan masalah yang akan dipecahkan.

Menurut Anwar (Aisyah, 2006: 14) bahwa investigasi diartikan sebagai penyelidikan dengan mencatat atau merekam fakta-fakta, melakukan peninjauan dengan tujuan memperoleh jawaban atas pertanyaanpertanyaan tentang suatu peristiwa, atau sifat.
Krismanto (2003: 7) mendefinisikan investigasi sebagai kegiatan pembelajaran yang memberikan kemungkinan siswa untuk mengembangkan pemahaman siswa melalui berbagai kegiatan dan hasil yang benar sesuai pengembangan yang dilalui siswa. Height (Krismanto, 2003: 7) menyatakan bahwa investigasi berkaitan dengan kegiatan mengobservasi secara rinci dan menilai secara sistematis. Jadi investigasi adalah proses penyelidikan yang dilakukan seseorang, dan selanjutnya orang tersebut mengkomunikasikan hasil perolehannya, dapat membandingkannya dengan perolehan orang lain, karena dalam suatu investigasi dapat diperoleh hasil satu atau lebih. Dengan demikian akan dapat dibiasakan untuk lebih mengembangkan rasa ingin tahu. Hal ini akan membuat siswa untuk lebih aktif berpikir dan mengungkapkan gagasan, serta dapat menarik kesimpulan berdasarkan hasil diskusinya di kelas.

Thelen (Joyce dan Weil, 1980: 232) menyatakan bahwa tiga konsep utama dalam pembelajaran investigasi kelompok yaitu inquiri, pengetahuan, dan dinamika kelompok belajar. Inquiri merupakan cara belajar penelaahan sesuatu yang bersifat mencari secara kritis, analisis, dan argumentatif dengan menggunakan langkah-langkah tertentu menuju suatu kesimpulan yang meyakinkan, karena didukung oleh data, fakta, dan argumentasi. Inkuiri dibangun di atas penemuan dan merupakan penemuan, sebab seorang siswa yang cara belajarnya dengan inkuiri dapat menggunakan kemampuankemampuan penemuannya untuk mengungkapkan suatu konsep atau prinsip. Pengetahuan merupakan suatu proses yang dilakukan oleh siswa secara terus-menerus untuk mencoba berbagai macam cara dalam melihat suatu pengalaman, kemudian menafsirkan kembali pengalaman itu dalam bentuk konsep atau prinsip-prinsip yang dapat dilaksanakan. Dinamika kelompok belajar merupakan suasana yang menggambarkan sekelompok individu yang saling berinteraksi mengenai sesuatu yang sengaja dilihat atau 
yang dikaji bersama yang melibatkan proses berbagi gagasan dan pendapat serta saling tukar pengalaman melalui proses saling berargumentasi. Kemudian siswa menganalisis unsur-unsur yang diperlukan, mengorganisasikannya, melaksanakan, dan melaporkan hasilnya.

Setiawan (2006: 10) mendeskripsikan fase-fase dalam pembelajaran investigasi kelompok diantaranya yaitu fase membaca, menerjemahkan, dan memahami masalah; fase pemecahan masalah; fase menjawab dan mengkomunikasikan jawaban. Sharan, et. al. (Krismanto, 2003: 8) mendesain model pembelajaran investigasi kelompok menjadi enam tahapan yaitu tahap mengidentifikasi topik dan pengelompokan; tahap merencanakan penyelidikan kelompok; tahap melaksanakan penyelidikan; tahap menyiapkan laporan akhir; tahap menyajikan laporan akhir; dan tahap evaluasi.

Berdasarkan pemaparan mengenai model pembelajaran investigasi kelompok di atas, dapatlah ditarik suatu kesimpulan bahwa model pembelajaran investigasi kelompok mendorong siswa untuk belajar lebih aktif dan lebih bermakna. Artinya siswa dituntut selalu berpikir tentang suatu persoalan dan mereka mencari sendiri cara penyelesaiannya. Dengan demikian mereka akan lebih terlatih untuk selalu menggunakan keterampilan pengetahuannya, sehingga pengetahuan dan pengalaman belajar mereka akan tertanam untuk jangka waktu yang cukup lama (Setiawan, 2006: 9).

Hasil belajar adalah penguasaan pengetahuan oleh seorang siswa yang diperoleh setelah mengikuti proses pembelajaran selama jangka waktu tertentu, biasanya dinyatakan dengan sebuah nilai sesuai dengan kemampuan yang diberikan oleh guru (Herrhyanto, 2002: 27). Hal ini sesuai dengan pendapat Dimyati dan Mudjiono (2002: 3) bahwa hasil belajar merupakan hasil dari suatu interaksi belajar dan tindak mengajar. Dari sisi guru, tindak mengajar diakhiri dengan proses evaluasi hasil belajar. Dari sisi siswa, hasil belajar merupakan berakhirnya puncak proses belajar. Hasil belajar siswa secara garis besar dibagi menjadi tiga aspek yaitu aspek kognitif, afektif, dan psikomotorik. Makmum (Puspitawati, 2005: 17) mengatakan bahwa untuk memudahkan perolehan data mengenai hasil belajar siswa ada beberapa indikator serta cara pengukurannya seperti pada Tabel 1 berikut.

Tabel 1. Indikator Hasil Belajar

\begin{tabular}{|c|c|c|}
\hline $\begin{array}{l}\text { Jenis Hasil } \\
\text { Belajar } \\
\text { Kognitif }\end{array}$ & Indikator & $\begin{array}{c}\text { Cara } \\
\text { Pengukura } \\
\mathbf{n}\end{array}$ \\
\hline Pengetahuan & $\begin{array}{l}\text { Dapat menyebutkan } \\
\text { /menunjukkan lagi }\end{array}$ & $\begin{array}{l}\text { Pertanyaan } \\
\text { /tugas /tes }\end{array}$ \\
\hline Pemahaman & $\begin{array}{c}\text { Dapat menjelaskan } \\
\text { /mendefinisikan dengan } \\
\text { kata-kata sendiri }\end{array}$ & $\begin{array}{l}\text { Pertanyaan } \\
\text { /tugas } \\
\text { /persoalan } \\
\text { /tes }\end{array}$ \\
\hline Aplikasi & $\begin{array}{l}\text { Dapat memberi contoh } \\
\text { /menggunakan dengan } \\
\text { tepat / memecahkan } \\
\text { masalah }\end{array}$ & $\begin{array}{l}\text { Tugas } \\
\text { /persoalan } \\
\text { /tes }\end{array}$ \\
\hline Analisis & $\begin{array}{l}\text { Dapat menguraikan } \\
\text { /mengklasifikasikan }\end{array}$ & $\begin{array}{c}\text { Tugas } \\
\text { /persoalan } \\
\text { /tes }\end{array}$ \\
\hline Sintesis & $\begin{array}{l}\text { Dapat menghubungkan } \\
\text { /menyimpulkan / } \\
\text { menggeneralisasikan }\end{array}$ & $\begin{array}{l}\text { Tugas } \\
\text { /persoalan } \\
/ \text { tes }\end{array}$ \\
\hline Evaluasi & $\begin{array}{c}\text { Dapat } \\
\text { menginterpretasikan / } \\
\text { memberi kritik } \\
\text { /memberi pertimbangan } \\
\text { /penilaian }\end{array}$ & $\begin{array}{l}\text { Tugas } \\
\text { /persoalan } \\
/ \text { tes }\end{array}$ \\
\hline Afektif & & \\
\hline Penerimaan & $\begin{array}{c}\text { Bersikap } \\
\text { menerima/sebaliknya }\end{array}$ & $\begin{array}{l}\text { Pertanyaan } \\
\text { /tes/ skala } \\
\text { sikap }\end{array}$ \\
\hline Sambutan & $\begin{array}{c}\text { Bersedia } \\
\text { terlibat/sebaliknya }\end{array}$ & $\begin{array}{c}\text { Tugas } \\
\text { /observasi/ } \\
\text { tes }\end{array}$ \\
\hline Penghargaan & $\begin{array}{c}\text { Memandang } \\
\text { penting/kagum/sebalikn } \\
\text { ya }\end{array}$ & $\begin{array}{c}\text { Skala } \\
\text { penilaian/tu } \\
\text { gas/observas } \\
\text { i }\end{array}$ \\
\hline Pendalaman & $\begin{array}{l}\text { Mengakui/mempercayai } \\
\text { /sebaliknya }\end{array}$ & $\begin{array}{c}\text { Tugas } \\
\text { ekspresif/ } \\
\text { skala sikap }\end{array}$ \\
\hline Penghayatan & $\begin{array}{c}\text { Menjelma dalam } \\
\text { kehidupan sehari-hari }\end{array}$ & $\begin{array}{l}\text { Observasi/ } \\
\text { tugas } \\
\text { ekspresif }\end{array}$ \\
\hline \multicolumn{3}{|l|}{ Psikomotorik } \\
\hline $\begin{array}{l}\text { Keterampilan } \\
\text { bertindak }\end{array}$ & $\begin{array}{l}\text { Koordinasi mata, tangan } \\
\text { dan kaki }\end{array}$ & $\begin{array}{l}\text { Tugas/obser } \\
\text { vasi/tes } \\
\text { tindakan }\end{array}$ \\
\hline $\begin{array}{l}\text { Keterampilan } \\
\text { ekspresi verbal } \\
\text { dan non verbal }\end{array}$ & Gerak, mimik, ucapan & $\begin{array}{l}\text { Tugas/ } \\
\text { observasi/tes } \\
\text { tindakan }\end{array}$ \\
\hline
\end{tabular}

Hasil belajar siswa bergantung pada usaha belajarnya, usaha belajar ini berarti segala kegiatan yang berhubungan dengan belajar dan bergantung pada tenaga, waktu, tempat 
Penerapan Pembelajaran Investigasi Kelompok Terhadap Hasil Belajar Matematis Siswa Sekolah Menengah Pertama

belajar, pelajaran tersebut, dan sebagainya. Dalam proses pembelajaran matematika terdapat sepuluh faktor yang mempengaruhi keberhasilan anak belajar yaitu kecerdasan anak, kesiapan anak, bakat anak, kemauan belajar, minat anak, model penyajian materi, pribadi dan sikap guru, suasana belajar, kompetensi guru, serta kondisi luar. Salah satu indikator keberhasilan suatu proses belajar mengajar dapat dilihat dari prestasi belajar siswa. Syamsudin (Juniawati, 2005: 18) menyatakan bahwa pendidikan pada hakekatnya merupakan usaha conditioning (pencapaian perangkat stimulus) yang diharapkan menghasilkan pola-pola perilaku (seperangkat respon tertentu). Indikatorindikator dari perubahan perilaku termaksud dapat dilihat pada prestasi belajar. Berdasarkan hal tersebut, indikator hasil belajar dalam penelitian ini adalah prestasi belajar siswa setelah mengikuti proses pembelajaran.

\section{METODE PENELITIAN}

Metode yang digunakan dalam penelitian ini adalah metode eksperimen. Penggunaan metode ini bertujuan untuk mengetahui sejauh mana pengaruh pembelajaran investigasi kelompok terhadap hasil belajar matematis siswa. Desain penelitian yang digunakan adalah desain kelompok kontrol pretes-postes.

\section{$\mathrm{A} \quad \mathrm{O} \quad \mathrm{X} \quad \mathrm{O}$}

\section{A $\mathrm{O} \quad \mathrm{O}$}

Populasi dalam penelitian ini adalah seluruh siswa SMP Negeri 40 Bandung. Sampelnya adalah siswa kelas VIII SMP Negeri 40 Bandung yang dipilih secara acak menurut kelas yaitu VIII J dan VIII K. Instrumen yang digunakan berupa tes uraian terdiri dari 5 soal yang telah diujicobakan disekolah yang sama untuk mengetahui keabsahan instrumen. Data yang diperoleh berupa data kuantitatif dari hasil pretes maupun hasil postes. Hasil pretes dan postes dianalisis menggunakan statistik parametrik dengan uji-t, karena data yang diperoleh berdistribusi normal dan homogen baik itu data pretes maupun data postes.

\section{HASIL DAN PEMBAHASAN}

Hasil analisis data pretes dan postes hasil belajar matematis siswa yang memperoleh pembelajaran investigasi kelompok maupun siswa yang memperoleh pembelajaran konvensional seperti pada Tabel 2 berikut.

Tabel 2. Deskripsi Data

\begin{tabular}{ccccc}
\hline \multirow{2}{*}{ Kelas } & \multicolumn{2}{c}{ Pretes } & \multicolumn{2}{c}{ Postes } \\
\cline { 2 - 5 } & Mean & $\begin{array}{c}\text { Std. } \\
\text { Deviation }\end{array}$ & Mean & $\begin{array}{c}\text { Std. } \\
\text { Deviation }\end{array}$ \\
\hline Eksperimen & 18.23 & 4.124 & 40.79 & 5.217 \\
\hline Kontrol & 16.79 & 3.833 & 38.17 & 5.049 \\
\hline
\end{tabular}

Berdasarkan Tabel 2 bahwa rata-rata hasil pretes kelas eksperimen adalah 18.23, sedangkan rata-rata kelas kontrol adalah 16.79. Standar deviasi kelas eksperimen adalah 4.124, sedangkan standar deviasi kelas kontrol adalah 3.833. Ini berarti bahwa rata-rata dan standar deviasi hasil pretes kelas eksperimen lebih baik daripada rata-rata dan standar deviasi kelas kontrol. Rata-rata hasil postes kelas eksperimen adalah 40.79, sedangkan rata-rata kelas kontrol adalah 38.17. Standar deviasi kelas eksperimen adalah 5.217, sedangkan standar deviasi kelas kontrol adalah 5.049. Ini berarti bahwa rata-rata hasil postes kelas eksperimen lebih baik daripada rata-rata kelas kontrol, sedangkan standar deviasi kelas eksperimen dan kelas kontrol tidak jauh berbeda.

Hasil analisis uji hipotesis statistik untuk data pretes hasil belajar matematis siswa kelas eksperimen dan siswa kelas kontrol seperti pada Tabel 3 berikut.

Tabel 3. Uji-t Data Pretes

\begin{tabular}{ccccc}
\hline $\begin{array}{c}\text { Levene's Test } \\
\text { for Equality of } \\
\text { Variances }\end{array}$ & t-test for Equality of Means \\
\hline F & Sig. & T & Df & Sig. (2-tailed) \\
\hline
\end{tabular}




\begin{tabular}{lrrrrr}
\hline Nilai & .087 & .769 & 1.762 & 92 & .081 \\
\cline { 2 - 5 } pretes & & & 1.762 & 91.511 & .081 \\
\hline
\end{tabular}

Berdasarkan Tabel 3 diperoleh nilai signifikansi (2-tailed) o.o81, ini berarti bahwa data pretes kelas eksperimen dan kelas kontol tidak berbeda secara signifikan. Siswa kelas eksperimen dan kelas kontrol memiliki kemampuan awal yang sama, sehingga proses pembelajaran investigasi kelompok dan pembelajaran konvensional diawali dengan kemampuan awal yang sama.

Hasil analisis uji hipotesis statistik untuk data postes hasil belajar matematis siswa kelas eksperimen dan siswa kelas kontrol seperti pada Tabel 4 berikut.

Tabel 4. Uji-t Data Postes

\begin{tabular}{cccccc}
\hline & $\begin{array}{c}\text { Levene's Test for } \\
\text { Equality of } \\
\text { Variances }\end{array}$ & \multicolumn{4}{c}{$\begin{array}{c}\text { Means } \\
\text { Mant for Equality of }\end{array}$} \\
\hline F & Sig. & T & Df $\begin{array}{c}\text { Sig. (2- } \\
\text { tailed) }\end{array}$ \\
\hline Nilaipostes & .042 & .838 & 2.471 & 92 & .015 \\
\cline { 2 - 6 } & & & 2.471 & 91.902 & .015 \\
\hline
\end{tabular}

Berdasarkan Tabel 4 diperoleh nilai signifikansi (2-tailed) o.015, ini berarti bahwa data postes kelas eksperimen dan kelas kontol berbeda secara signifikan. Hasil belajar matematis siswa yang memperoleh pembelajaran invetigasi kelompok lebih baik daripada hasil belajar matematis siswa yang memperoleh pembelajaran konvensional.

Berdasarkan hasil analisis data, ternyata hasil belajar matematis siswa yang memperoleh pembelajaran investigasi kelompok lebih baik daripada hasil belajar matematis siswa yang memperoleh pembelajaran konvensional. Hal ini disebabkan dalam pembelajaran investigasi kelompok keterlibatan siswa yang sangat diutamakan. Dalam pembelajaran investigasi kelompok, siswa dilibatkan dalam perencanaan pembelajaran, baik dalam pemilihan atau pembagian tugas investigasi dan cara-cara memulai investigasi mereka. Pembelajaran investigasi kelompok lebih menekankan pengembangan pemecahan masalah dalam suasana demokratis dimana pengetahuan tidak diajarkan secara langsung kepada siswa melainkan diperoleh melalui proses pemecahan masalah. Pembelajaran investigasi kelompok lebih mengaktifkan siswa dalam melakukan interaksi dan membangun gagasangagasan yang kreatif antar teman dalam kelompok. Belajar aktif dapat menyebabkan ingatan siswa menjadi lebih luas dibandingkan dengan belajar pasif. Oleh karena itu siswa diberikan kebebasan dan kesempatan untuk menerapkan gagasan-gagasan mereka sendiri yang diperoleh dari hasil penyelidikan dan penemuan yang dilakukan dalam kelompok kecil.

Sementara tahapan-tahapan dalam investigasi kelompok yaitu identifikasi topik dan mengatur siswa ke dalam kelompok, merencanakan tugas belajar, melaksanakan tugas investigasi, mempersiapkan laporan akhir, dan evaluasi. Berdasarkan temuan peneliti siswa mengalami hambatan melaksanakan salah satu tahap dalam tahapan-tahapan investigasi di atas yakni pada tahap melaksanakan tugas investigasi. Semua anggota dalam kelompok diharuskan memberikan usaha pada kelompoknya berupa saling tukar pikiran, berdiskusi, dan mengeluarkan gagasangagasan tetapi tidak semua anggota kelompok melaksanakannya. Hanya sebagian saja yang melakukannya dan yang lainnya cenderung pasif. Efek free rider adalah suatu kondisi dimana beberapa anggota dalam kelompok mengerjakan semua atau sebagian pekerjaan dalam pembelajaran, sedangkan yang lainnya tidak melakukan aktivitas. Disinilah peranan guru sebagai motivator dan fasilitator yang bertugas untuk memotivasi siswa yang pasif agar mau untuk mengeluarkan pendapatnya dan lebih aktif dalam memberikan sumbangan berupa pikiran terhadap kelompoknya. Di kelas 
Penerapan Pembelajaran Investigasi Kelompok Terhadap Hasil Belajar Matematis Siswa Sekolah Menengah Pertama

yang menerapkan pembelajaran investigasi kelompok, guru berperan sebagai konselor, konsultan, dan pemberi kritik yang bersahabat.

\section{KESIMPULAN}

Berdasarkan hasil analisis data dan uji hipotesis statistik diperoleh kesimpulan bahwa hasil belajar matematis siswa yang memperoleh pembelajaran investigasi kelompok lebih baik daripada yang memperoleh model pembelajaran konvensional. Hasil penelitian menunjukkan bahwa pembelajaran investigasi kelompok memberikan pengaruh yang baik terhadap hasil belajar matematis siswa, sehingga pembelajaran investigasi kelompok dapat dijadikan suatu alternatif dalam memilih dan menerapkan suatu metode dalam proses pembelajaran matematika untuk menciptakan suasana belajar yang menyenangkan dan memudahkan siswa dalam memahami materi yang diberikan.

\section{DAFTAR PUSTAKA}

Aisyah, A. (2006). Pengaruh Penerapan Model Pembelajaran Investigasi Kelompok terhadap Kemampuan Pemecahan Masalah Matematika. Skripsi Jurusan Pendidikan Matematika UPI. Bandung: tidak diterbitkan.

Apriyanto, G. (2002). Penggunaan Kalkulator Grafik dalam Pembelajaran Matematika untuk Menumbuhkan Kemampuan Penalaran dan Komunikasi Matematika Siswa SLTP. Skripsi FPMIPA UPI. Bandung: tidak diterbitkan.

Dimyati dan Mudjiono. (2002). Belajar dan Pembelajaran. Jakarta: Rineka Cipta.

Herrhyanto, N. (2002). Pengaruh Bakat, Minat, dan Kebiasaan Belajar terhadap Hasil Belajar Matematika
Mahasiswa. Tesis PPS UPI. Bandung: tidak diterbitkan.

Joyce dan Weil. (1980). Models Of Teaching. London: Prentice-hall.

Juniawati, N. (2005). Pengaruh Strategi ThinkTalk-Write terhadap Hasil Belajar Matematika Siswa SMP. Skripsi FPMIPA UPI. Bandung: tidak diterbitkan.

Krismanto, Al. (2003). Beberapa Teknik, Model, dan Strategi dalam Pembelajaran Matematika. http//www.duniaguru.com/doc/mat ematika/sma/sistempembelajaranm atematikaPdf (diakses 5 februari 2008).

Mafruroh, S. (2004). Kemampuan Menyelesaikan Soal-soal Essay Fisika dengan Menggunakan Model Investigasi Kelompok pada Pokok Bahasan Impuls dan Momentum. Skripsi UPI. Bandung: tidak diterbitkan.

Nia, K., Effendi, S., \& Farlina, E. (2017). Kemampuan Berpikir Kreatif Siswa SMP kelas VII dalam Penyelesaian Masalah Statistika. Analisa, 3(2), 130-137.

Ruseffendi, E. T. (1991). Pengantar kepada Membantu Guru Mengembangkan Kompetensinya dalam Pengajaran Matematika untuk Meningkatkan CBSA. Bandung: Tarsito.

Setiawan (2006). Model Pembelajaran Matematika dengan Pendekatan Investigasi. http/58.145.171/web/ppp/ppp_pend ekatan_investigasi.Pdf. (diakses 29 januari 2008).

Suwangsih, E. (2004). Peningkatan Kemampuan Pemecahan Masalah 
Matematika Siswa Sekolah Dasar melalui Pembelajaran Kooperatif. Tesis PPS UPI Bandung: tidak diterbitkan.

Wahyudin (1999). Kemampuan Guru Matematika, Calon Guru Matematika dan Siswa dalam Mata Pelajaran Matenatika. Disertasi FPMIPA UPI. Bandung: tidak diterbitkan.

Yunita dan Poedjadi, A. (2001). Kolaborasi dengan Universitas di SMUN 8 dalam Rangka Meningkatkan Kualitas Pendidikan Kimia. Seminar Procceding National on Science and Mathematics Education. JICA: IMSTEP FPMIPA UPI. 